\title{
The Anthelminthic Effectivity of Gandarusa Leaves (Justiciagendarussa Burm. F.) Infusion and Kapok Seed Infusion (Ceibapentandra L.) Against Female Ascarissuum In Vitro
}

\author{
Rita Tjokropranoto $^{1, a^{*}}$,Cherry Azaria ${ }^{2}$, Manasye Jutan ${ }^{3}$,Said Muh.Faros Ghalib ${ }^{3}$ \\ ${ }^{1}$ Department Parasitology Medicine Faculty of Maranatha Christian University \\ ( Jl.Prof,drg. Suria Sumantri no.65 Bandung 40164) \\ ${ }^{2}$ Department Histology Medicine Faculty of Maranatha Christian University. \\ 3Medicine Faculty of Maranatha Christian University \\ ${ }^{a)}$ Corresponding author: rita.tjokropranoto788@gmail.com
}

\begin{abstract}
Ascariasis is known as "soil transmitted helminths" which persons were infected by ingesting eggs were passed in the feces. The most prevalence of Ascariasis in school children are more than $30 \%$, with resultant impairment in growth retardation, intellectual, and cognitive development. The purpose of this research was to determine the anthelminthic effectivity of Gandarusa Leaves Infusion (GLI), Kapuk Seed Infusion (KSI) were the same as pyrantelpamoat as against female Ascarissuum in vitro. Methods of the research was true laboratory experimental, using 1200 female worms of Ascarissuum, which GLI and KSI treatment were divided into 8 treatment groups (GLI1, GLI2, GLI3, GLI4 and KSI1, KSI2, $\mathrm{KSI} 3$, KSI4), one negative control with $\mathrm{NaCl}$, positive control with pyrantelpamoat. The treatment groups were incubated at $37^{\circ} \mathrm{C}$ for 3 hours. The data measured were number of paralyzed and dead worms. Data was analyzed using ANOVA, followed by Tukey HSD test $\alpha=0.05$. The results showed that the highest percentage number of paralyzed and dead worms on GLI 4 was $70 \%$, on KSI4 was $40.83 \%$, GLI 4 was not significant ( $p>0.05$ ) with pirantelpamoat. GLI and KSI contain various compound such as alkaloid, tannin and saponin. Conclusion GSI 4 had an anthelminthic effectivity the same as with pirantelpamoat.
\end{abstract}

Keywords: athelminthic, Ascarissuum, Gandarusa Leaves Infusion, Kapok Seed Infusion

\section{INTRODUCTION}

Ascariasisis caused by intestinal nematode such as Ascarislumbricoides. Ascariasis infection is known as "the one main of soil-transmitted helminth infections". The people were infected Ascarislumbricoides by ingestion of fully developed eggs in raw vegetables. ${ }^{(1,2)}$ The prevalence peak of ascariasis infections are in children between aged 5-15 years, wich resultant inmalnutrition, growth stunting, intellectual retardation, impaired in physical, cognitive development, and educational deficits. ${ }^{(2,3)}$ The heavy infection of ascariasis causing ileus obstructive. ${ }^{(4)}$ The Ascariasis disease is the helminthicinfection in tropical developing 
country, which responsible in estimated 60.000 deaths every year ${ }^{(5)}$ Ascariasisinfection is a risk factor for human with poor personal hygiene, poor sanitation and human feces are used as a ferlilizer. ${ }^{(6)}$

Drug of choice of the Ascariasis disease are albendazole, mebendazole and pyrantelpamoat especially for pregnance woman, nevertheless pyrantelpamoat causing intestinal gangrene, fever, headache, abdomen cram, tenesmus, nausea, vomitus, paralysis vermifuges which should be avoided in patients with intestinal obstruction.. ${ }^{(7)(8)}$ The alternative therapies for managing ascariasiscould be used herbs such as gandarusa leaves and kapok seed. Extract leaf and stem gandarusahad activity anthelmintic against Lumbricus worm. ${ }^{(9)}$ The purpose of this research was to determine the anthelminthic effectivity of Gandarusa Leaves Infusion (GLI), Kapuk Seed Infusion (KSI) were the same as pyrantelpamoat as against female Ascarissuumin vitro.

\section{METHOD AND MATERIALS}

The method of the research was true laboratory experimental) using 1200 female worms of Ascarissuum, which were divided into 8 groups $(r=4)$, group I, II, III, and IV were given Gandarusa Leaf Infusion (GLI) dose of 10\%, 20\%, 40\%, 80\%, and 100\% respectively, group VI, VII, VII and VIII were given Kapok Seed Infusion, group IX was given $\mathrm{NaCl} 0.9 \%$ solution as a negative control and group $\mathrm{X}$ was given $0,05 \%$ pyrantelpamoate suspension as a positive control. Treatment groups were incubated at $37^{\circ} \mathrm{C}$ for 3 hours. The data measured was average percentage of dead worms. Data was analyzed using ANOVA, followed by Tukey HSD test, $\alpha=0.05$.

\section{MATERIALS}

Gandarusa Leaves, Kapok seeds, $\mathrm{NaCl}$ 0,9 \% solution, water, pirantelpamoat 0,05\% suspension.

\section{TOOLS}

Becker glass, measuring cup, incubator, infusa pan, strainer, chopstick, knife, handscoen, thermometer, timer, stir bar, stopwatch, plastic container.

\section{RESULTS}

All of herbs of Gandarusa Leaf Infusion (GLI) and Kapok Seed Infusion had anthelmintic effectivity against Ascarissuum. The result of GLI 4 withconcentratin $80 \%$ had no significance activity with positive control (pyrantelpamoat). GLI 4 had the same as effectivity withpyrantelpamoat $0.05 \%$. Thehighest average percentage number of paralysed and dead worms was on Gandarusa Leaf Infusion(GLI) 4 was $69.97 \%$ after incubation on 3 hours at 37 ${ }^{\circ} \mathrm{C}$. 


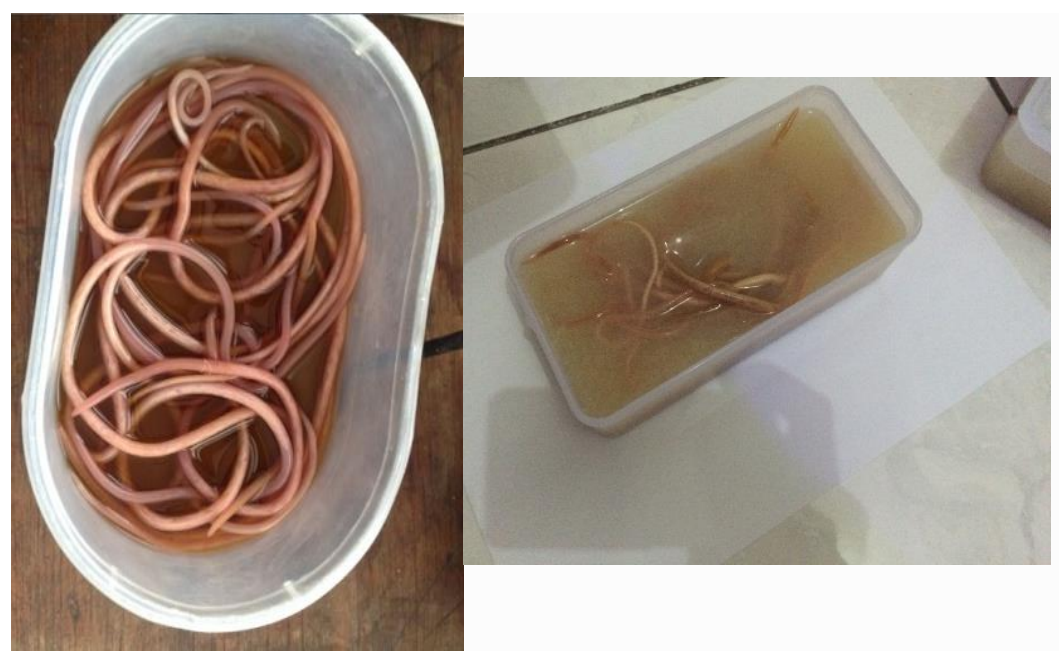

(a)

(b)

FIGURE.1 (a) Ascarissuum in Gandarusa Leaf Infusion (b) Ascarissuum in Kapok Seed Infusion

TABLE 1 : ANOVA average percentage dead of Ascarissuum

\section{ANOVA}

$\log$

\begin{tabular}{|l|r|r|r|r|r|}
\hline & Sum of Squares & df & Mean Square & F & Sig. \\
\hline Between Groups & 3.379 & 9 & .375 & 97.979 & .000 \\
Within Groups & .115 & 30 & .004 & & \\
Total & 3.494 & 39 & & & \\
\hline
\end{tabular}


TABLE 2. Post Hoc Tukey HSD

\begin{tabular}{|c|c|c|c|c|c|c|c|c|c|c|c}
\hline No & Treatment & I & II & III & IV & V & VI & VII & VIII & Control & Control \\
$(-)$
\end{tabular}

Table caption

I : Gandarusa Leaf Infusion $10 \%$

II : Gandarusa Leaf Infusion $20 \%$

** : Highly Significance

* : Significance

$(<0.05)$

III : Gandarusa Leaf Infusion 40\%NS : Non Significance $\quad(\geq 0.05)$

IV : GandarusaLeaf Infusion $80 \%$

$\mathrm{V}$ : Kapok Seed Infusion 2.5\%

VI : Kapok Seed Infusion 5\%

VII: Kapok Seed Infusion 7.5\%

VIII : Kapok Seed Infusion 10\%

Control (+) :PyrantelPamoat $0.05 \%$

Control (-) : $\mathrm{Na} \mathrm{Cl} \mathrm{0.9 \%}$

\section{DISCUSSION}

All of the Gandarusa Leaf Infusion (GLI) had anthelmintic effectivity against Ascarissuum because GLI containing alkaloid and saponin compound which inhibition kolinesterase enzyme so that acetycholine is not broken out, resulting in acetylcholine accumulates on neuromuscular nicothinic receptor due to increasing muscle contraction than continuous stimulating nichotinic receptor that causing muscle paralyzed and dead of Ascarissuum. ${ }^{(10-}$ ${ }^{12}$ Saponinis also can causing gastrointestinal irritation to Ascarissuum. ${ }^{(11)}$. Tannin compound contained in GLI could changing membrane permeability and denaturation protein that disturbing haemostasis metabolism resulting in dead worm. ${ }^{(13)}$ GLI 4 concentration $80 \%$ had the same as effectivity with pyrantelpamoat, it was resulting in the same as mechanism 
between alkaloid, saponin compound with pyrantelpamoathad activity like as blocking the neuromuscular system of the worm, which becomes instantly immobilized.

\section{CONCLUSION}

Gandarusa Leaf infusion concentration $4(80 \%)$ had an anthelminthic effectivity the same as with pirantelpamoat.

\section{REFERENCE}

1. Galzerano A, Sabatini, E and Duri, D. Ascaris lumbricoides infection : an unexpected cause of pankreatitis in a western Mediterranean country. Eastern Mediterranean Health Journal. 2010;16(3):350-1.

2. Bethony J, Brooker, Simon., Albonico, Marco., Geiger, Stefan,M.,Loukas, Alex ., Diemert, David and Hotez, Peter,J. Soil- transmitted helminth infections : ascariasis, trichuriasis and hookworm. Lancet. 2006;367:1521-32.

3. Hogtez P, J., Brindley, Paul,J., Bethony, Jeffrey,M., King, Charles,H., Pearce, edward,J., and Jacobson, Julie. Helminth infections : the great neglected tropial diseases. The Journal of Clinical Investigation. 2008;118(4):1311-21.

4. Margono S, S. Nematoda Usus. In: Gandahusada S, editor. Parasitologi Kedokteran. Jakarta: Fakultas Kedokteran Universitas Indonesia; 2006. p. 7-11.

5. Keating A, Quigley, James Aidan., and Genterola, Al Frederick. Obstructive Jaundice induced by biliary ascariasis. BMJ. 2012:1-3.

6. CDC. Ascariasis 2015 [cited 2016]. Available from: http://www.cdc.gov/parasites/ascariasis/.

7. Ascariasis treatment and management [Internet]. emedicine.medscape. 2015.

8. Syarif A. aE. Antelmintik. Farmakologi Dan Terapi. Jakarta: Departemen Farmakologi dan Terapeutik Fakultas Kedokteran Universitas Indonesia.; 2007. p. 541-50.

9. Saha M R. DPC, Rahman M A., and UI Islam M A Evaluation of in vitro anthelmintic activities of leaf and stem extracts of justicia gendarussa. A Journal of the Bangladesh Pharmacological Society. 2012:50-3.

10. Kuntari TDAardkCaLtctaivYUII. Daya Antihelmintik air rebusan daun ketepeng (Cassia alata L.) terhadap cacing tambang anjing in vitro. . Yogyakarta: Universitas Islam Indonesia; 2008.

11. Mills S, and Bone, K Principles and Practice of Phytotheraphy : Modern herbal Medicine. New York: Elsevier; 2000.

12. Cholinesterase Inhibitors: Including Pesticides and Chemical Warfare Nerve Agents. Agency for Toxic Substances and Disease Registry Case Studies in Environmental Medicine. [Internet]. 2010. Available from: http://www.atsdr.cdc.gov/csem/cholinesterase/docs/cholinesterase.pdf

13. Sandika B, Raharjo, and Ducha, N Pengaruh pemberian air rebusan akar delima (Punica granatum L.) terhadap mortalitas ascaris suum Goeze. secara in vitro. Lentera Bio, 2012;1(2):81-6. 